\title{
Theories of Pragmatics and Its Applications in EFL
}

\author{
Yong Chi \\ School of Foreign Languages \\ Yangtze University \\ Jingzhou, Hubei 434023
}

\begin{abstract}
By analyzing the specific examples from the textbooks of College English, this paper discusses the basic theories of pragmatics: deixis, presupposition, the cooperative principle, the politeness principle, investigates the applications of the theories in College English teaching, and points out the significance of pragmatics in EFL.
\end{abstract}

Keywords-pragmatics; deixis; presupposition; cooperative principle; politeness principle: $\mathrm{EFL}$

\section{INTRODUCTION}

The term pragmatics was first invented into the literature by the American philosopher Charles William Morris in 1937, when he collected five of his papers written after 1934 and published them under the title Logical Positivism, Pragmatism and Scientific Empiricism. In his Foundations of the Theory of Signs published in 1938, Morris divided semiotics into three branches: syntactics, semantics and pragmatics[1]. After that the study of pragmatics was only restricted to the field of philosophy. Pragmatics became an independent subject until the publication of Journal of Pragmatics. At the beginning pragmatics was considered the wastebasket of linguistics. But it has been developing rapidly. By the early 1980s pragmatics had generally accepted as one of the basic branches of linguistics. And now it is one of the rapidly growing fields in contemporary linguistics.

The central topics of pragmatics are deixis, presupposition, speech acts, conversational implicature, the cooperative principle, the politeness principle, and the relevance theory and discourse analysis. In this paper, the author mainly discusses the theories of deixis, presupposition, the cooperative principle, the politeness principle and their applications in College English teaching.

\section{The Applications of Theories of Pragmatics in EFL}

\section{A. Deixis}

\section{1) Theory}

Deixis is the first area of study in linguistic pragmatics that caught the attention of scholars. Deixis is the function of grammatical as well as lexical means relating a piece of language to its context in terms of its users, the time and place of its occurrence, and the people and objects it refers to. The words used in this function are known as deictics, indexicals, or indexical expressions. Typical examples are pronouns, demonstratives, time and place adverbs, and some grammatical categories such as tense. In terms of the semantic content of the deictic words, they may be divided into five groups: (1)person deixis, such as I, me, you, he, him, she, herself, they, it, and etc.
(2) time deixis, such as now, then, today, tomorrow, and etc. (3) place deixis, such as here, there, in(side), out(side), up(stairs), down(stairs), nearby, far away, opposite, behind, and etc. (4) discourse deixis, such as this, that, in the last paragraph, in the next chapter, and etc. (5) social deixis, such as the editorial we, the polite form of the second person pronoun.

Deixis deals with the ways in which language encodes features of the context of utterance or speech event, and thus also deals with the ways in which the interpretation of utterance depends on the analysis of the context of that utterance. Let's compare the three sentences given by Yohoshua Bar-hillel (1954)[2].

(1) Ice floats on water.

(2) It's raining.

(3) I'm hungry.

The first sentence would not cause any difficulty for its interpretation in isolation. Whoever says at whatever time and place, its meaning would not change. But the second and the third sentences, which contain indexical expressions, depend on the context heavily.

\section{2) Application}

We can see how Emest Hemingway uses the indexical "it" to achieve his writing purpose in his short novel A Day's Wait, in which he shows the feelings of a nine-year-old boy who, through a misunderstanding, undergoes a shattering experience. The following is the dialogue between a father and a son. you."

"You don't have to stay in here with me, Papa, if it bothers

"It doesn't bother me.”

"No, I mean you don't have to stay if it is going to stay." about."

"Your temperature is alright." I said. "It's nothing to worry

"I don't worry," he said, "but I can keep from thinking."

"Don't think.” I said, "Just take it easy.”

'T'm taking it easy." he said and looked straight ahead [3]

Obviously, the father and the son are thinking of different things when they talked to each other. The misunderstanding between them caused by the different references of the indexical "it". In their talking the father's "it" refers to 'the flu", while the son's "it" refers to "the death". From the misunderstanding of the father and the son, we can see how brave the son is: in facing 
crisis, the boy shows no fear and controls his emotions manfully.

\section{B. Presupposition}

\section{1) Theory}

A presupposition is something the speaker assumes to be the case prior to making an utterance (Yule 1996) [4]. It is the speakers who have presuppositions. Let's look at the famous example given by Cottlob Frege (1892), the German philosopher who first attracted the notice of the scholarly world[5].

(1) Kepler died in misery.

We can identify some of the potentially assumed information that would be associated with the utterance (1). In producing the utterance in (1), the speaker will normally be expected to have the presupposition that a person called Kepler exited, because without the existence of Kepler, one cannot talk about his dying in misery.

As a matter of fact, presupposition has something to do with the linguistic knowledge, encyclopedia knowledge. Background knowledge, and common sense, all of which will help us to understand the meaning of presupposition. Understanding the meaning of presupposition will be beneficial to various parts of English learning: listening, speaking, reading, writing and speaking.

\section{2) Application}

We can also see how Ernest Hemingway uses presupposition to make a well-knit story in his short novel $A$ Day's Wait. At the beginning of the story, Hemingway writes, he (the boy) came into the room to shut the windows while we were still in bed and I saw he looked ill. He was shivering, his face was white, and he walked slowly as though it ached to move.

"What's the matter, Schats?"

'I've got a headache."

"You'd better go back to bed."

"No, I'm all right."

But when I came downstairs he was dressed, sitting by the fire, looking a very sick and miserable boy of nine years, when I put my hand on his forehead, I knew he had a fever.

"You go up to bed," I said, "you're sick."

"T'm all right." he said.

When the doctor came, he took the boy's temperature. (College English III)

The sentence "He came to shut the windows ... "presupposes "the windows had been open." From the presupposition we know the family in the story might have the habit of sleeping with the windows open, even in winter when the temperature outside is below zero degree $\mathrm{C}$. The boy has a headache; he guesses he has got a cold, so he goes to his parents' room to close the windows. He doesn't want his parents to catch cold as he has done. Another sentence "When the doctor came" presupposes there was a doctor and someone called in the doctor. We know the author uses the presupposition tactfully. He doesn't tell us how the boy went upstairs to bed and how the father called in the doctor to treat him. He has omitted what can be omitted to make a well-knit story.

\section{The Cooperative Principle (the CP)}

\section{1) Theory}

In the theory of conversational implicature Grice (1975) suggests that there is an underlying principle that determines the way in which language is used maximally efficiently and effectively to achieve rational interaction in communication. He called the governing dictum the cooperative principle and elaborated in four sub-principles, called maxims, as shown in the following.

The Maxims

Quantity

(1)Make your contribution as informative as is required (for the current purposes of the exchange).

(2) Do not make your contribution more informative than it is required.

Quality Try to make your contribution one that is true.

(1) Do not say what you believe to be false

(2) Do not say that for which you lack adequate evidence.

Relation be relevant

Manner be perspicuous

(1)Avoid obscurity of expression

(2)Avoid ambiguity.

(3)Be brief (avoid unnecessary prolixity).

(4)Be orderly. (Grice: 1975[6]).

In the conversation, we will try to say things which are true, relevant, as well as informative enough, and in a clear manner. Hearers will also try to interpret what is said to them in this way. If there are obvious signs that one, or more, of the maxims is not followed, one will try to find out the reason, as long as the $\mathrm{CP}$ and the speaker may still be thought to be observing the CP. And it is usually the case that there is some extra meaning intended. In this sense, the CP may be the answer offered by Grice to the question of conversational implicature. In a sense, the theory conversational implicature may be seen as an attempt to explain how communication succeeds in the face of violation of the maxims.

\section{2) Application}

a) Violation of quantity \& quality maxim

Let's take the well-known short story The Luncheon by William Somerset Maugham as an example. In the story, Maugham describes a young writer who had to invite a lady to lunch.

Let's check the talk between them.

'I never eat anything for luncheon."she said.

"Oh, don't say that." I answered generously. 
"I never eat more than one thing. I think people eat too much nowadays. A little fish, perhaps, I wonder if they have any salmon...."

The waiter asked her if she would have something while it was being cooked.

"No," she answered, 'I never eat more than one thing unless they have a little caviar, I never mind caviar."

...

Then came the question of drink.

'I never drink anything for luncheon, "she said.

"Never do I." I answered promptly.

"Except white wine." she proceeded as though I had not spoken.

"The French wines are so light. They are wonderful for the digestion."

"What would you like?" I asked, hospitable still, but not exactly effusive. She gave me a bright and amicable flash of the white teeth.

"My doctor let me drink nothing but champagne."[7]

When the lady said, "I never drink anything for luncheon", "I" answered promptly, "Never do I". Here "I" the writer violates the quality maxim, because he says something he himself believes to be false. The reason why the writer says so is that he has no money. Maybe he wants the lady to understand his implied meaning at the same time, but the lady neglects his response, and orders champagne. The writer describes himself, mentions casually that my doctor had absolutely forbidden me to drink champagne. The writer violates the quality maxim again.

The lady in the dialogue violates the quality maxim and the quantity maxim as well. When she says, 'I never eat any luncheon", she is telling a lie, because she intended to have a big luncheon. Here she violates the quality maxim. But the writer believes her at the very beginning, so he says generously, "Oh, don't say that." Every time before she orders something, she always says, "I never eat more than one thing." Then she begins to supply either not enough or unnecessary information. Here she violates the quantity maxim, which requires the participants of the conversation to make your contribution as informative as is required (for the current purposes of the exchange), not to make your contribution more informative than it is required. Her purpose of doing so is to catch the young writer in the trap she sets. The irony of the situation, the rich understatement of the dialogue and the humorous narrative combine to make the story very entertaining. Especially colorful dialogue between the writer and the lady coins the hero and heroine of the story vividly: an inexperienced and impoverished young writer, and a greedy cunning, and faceless middle-aged woman.

\section{b) Violation of relation maxim}

Let's take the story You Go Your Way, I'll Go Mine by William Saroyan as an example. In the story, the author describes a boy who suddenly finds himself in a situation he is not prepared to cope with and a woman who grieves at the sad news of her son's death. Let's have a look at the talk between the boy and the woman.

"No, ma'am." Homer said, "The telegram is from the War Department."

\section{"War Department?" the Mexican woman said.}

Mrs. Sandoval. Homer said swiftly, "Your son is dead."

"Maybe it's a mistake. Everybody makes a mistake, Mrs. Sandoval. Maybe it wasn't your son. Maybe it was somebody else. The telegram says it was Juan Domingo. But maybe the telegram is wrong."

The Mexican woman pretended not to hear.

"Oh, do not be afraid." she said, "Come inside, come inside. I will bring you candy." She took the boy's arm and brought to the table at the center of the room and there she made him sit.

"All boys like candy."she said, "I will bring you candy.” She went into another room and soon returned with an old chocolate candy box. She opened the box at the table and in it Homer saw a strange kind of candy.

"Here,” she said, "eat this candy. All boys like candy."

Homer took a piece of candy from the box, put it into his mouth, and try to chew [8].

Homer, the boy, is the bearer of the tragic news which would surely cause pain and unhappiness to the woman. To less the grief of the woman, the boy uses four "maybe" to cover up the sad news, even though the name of her son is written clearly on the telegram. The boy tells something he doesn't believe to be true, violating, the quality maxim. He does not want to hurt her, as is the intention of his violating the quality maxim. But the woman doesn't show deep grief after hearing the news, and talks something which has nothing to do with the event. She says "Oh, do not be afraid. Come inside. Come inside. I will bring you candy." Obviously, the lady violates the relation maxim, because she says something irrelevant. She refuses to believe it, though she hears for certain that her son is dead. From their conversation, we can see how kind-hearted the boy is and how awkward and helpless he is. We can also feel the grief of the woman, even though she pretends to neglect the news.

\section{The Politeness Principle (the PP)}

\section{1) Theory}

Although Grice supposes that the participants in the conversation have the desire to communicate successfully in a rational and cooperative way, and in order to achieve the purpose they must to obey the maxims of the CP. But the CP in itself cannot explain why people are so indirect in conveying what they mean. So Leech (1983) puts forward the politeness principle to be added to the CP. The PP is not only a necessary complement, but also rescues the $\mathrm{CP}$ from serious trouble. Leech divided the PP into six maxims, each maxim includes two sub-maxims.

\section{(1)Tact maxim (in impositives and commissives)}

(2) Generosity maxim (in positives and commissives) 
(3)Approbation maxim (in expressives and assertives)

(4)Modesty maxim (in expressives and assertives)

\section{(5)Agreement maxim (in assertives)}

\section{6) Sympathy maxim (in assertives)[9]}

Leech uses the PP to save the CP, so the PP can only solve some problems that couldn't be solved by the CP, but it cannot solve all the problems of polite language, especially the common phenomena of polite language. Comparatively, face-saving theory suggested by Brown and Levinson (1978) seem to be clearer and more practical [10]. According to them, politeness is the rational act taken by a "model person (MP)" to satisfy his "face wants". When we attempt to save another's face, we can pay attention to their positive wants and their negative face wants. A person's positive wants is the need to be accepted, even liked by others, to be treated as a member of the same group, and to know that his or her wants are shared by others. A person's negative face wants is the need to be independent, to have freedom of action, and not to be posed by others. In simple words, positive face is the need to be connected and negative face is the need to be independent. A face saving act is oriented to the person's positive face is called positive politeness. A face saving act is oriented to the person's negative face is called negative politeness.

\section{2) Application}

Let's look at the story The Sampler adapted from a short story of the same title by the American author IV Morris. It describes a brief encounter of a young man with an elderly gentleman in a store during the Christmas season. Probably the gentleman has come down in the world and sampling the puddings is all that left him from the time when he could afford to come and select his favorite pudding. In a burst of benevolence, he goes up to him and said:

'Pardon me, sir, will you do me a favor? Let me purchase you one of these puddings. It would give me such pleasure."

He jumped back as if he had been stung, and the blood rushed into his wrinkled face.

"Excuse me," he said, with more dignity than I would have thought possible considering his appearance, "I do not have the pleasure of knowing you. Undoubtedly you have mistaken me for someone else." And with a quick decision he turned to the shop girl and said in a loud voice, "Kindly pack me up this one here, I will take it with me." He pointed at one of the largest and most expensive of the puddings [8].

What the young man says interferes the elderly gentleman's freedom of action and his independence. Every one has the right to sample the puddings, even without the intention of buying any. Actually he is threatening the gentleman's "negative face wants". The old man did not expect that one of the customers would come up and offer to buy one of the puddings, that's why he jumped back as if he had been stung. The old man violates the relation maxim, because what the old man says seems to have nothing to do with the young man's question. The gentleman's "negative face wants" is threatened, and he chooses to counter back with words. His choice of words is rather impressive. In response to the young man's offer, he switches to a high level of speech. The language is very polite apparently, but rather stiff and cold actually. By doing this he wants to tell the young man he is dignified and well-educated. He feels humiliated, resentful, indignant, and takes the young man's offer as an insult. This is what the old man wants to convey to the young man by violating the relation maxim. To save his "honor" he is forced to buy which he could not possibly afford. At last the young man regrets, "How I longed for the power to unsay my tactless words! It was too late though."

\section{CONCLUSION}

From the discussion in the previous paragraphs we know Pragmatics is a new field in linguistic study, but it has powerful ability of theoretical analysis. It provides us with a complete new perspective in EFL. It can broaden the students' horizon, arouse their interests, and develop their pragmatic ability.

\section{REFERENCES}

[1] Morris, C. W. (1938). Foundations of the Theory of Signs. In Morris(1971)

[2] Bar-Hill, Y. (1954). Indexical Expression. Mind. (Reprinted in BarHillel(1970))

[3] Zhai Xiangjun. (1997). Intensive Reading of College English III. Shanghai: Shanghai Foreign Language Education Press

[4] Yule, G. (1996). Pragmatics. London: Oxford: Oxford University Press

[5] Frege. G. (1892). On Sense and Reference. In Reach \& Blake (ed. ) (1952)

[6] Grice, H. P. (1975). Logic and Conversation. In P. Cole \& J. L. Morgan (ed. ): Syntacx and Semantics Volume: Speech Acts. Academic Press (1975)

[7] Li Yin-hua, (1997). Intensive Reading of College English (revised) Volume 4. Shanghai:Shanghai Foreign language Education Press

[8] Zhai Xiangjun. (1997). Intensive Reading of College English I. Shanghai: Shanghai Foreign language Education Press

[9] Leech, G. (1983). Principles of Pragmatics. London: Longman

[10] Brown, P. \& Levinson, S. Universals in Language Usage: Politeness Phenomena. In Goody, E(ed. ), Questions and Politeness in Social Contest. Harmondsworth:Penguin, 1972 